\title{
Grunto, veikiamo periodinèmis apkrovomis, elgsenos tyrimai
}

\author{
Šarūnas Skuodis, \\ Rokas Karpis, \\ Mindaugas Zakarka, \\ Modestas Gedvilas, \\ Vytautas Raginis, \\ Kornelija Orlova, \\ Mantas Katauskas \\ Vilniaus Gedimino technikos universitetas, \\ Statybos fakultetas, \\ Gelžbetoniniu konstrukciju \\ ir geotechnikos katedra, \\ Sauletekio al. 11, 10223 Vilnius, Lietuva \\ El.paštas sarunas.skuodis@vgtu.lt
}

Skuodis Š, Karpis R., Zakarka M., Gedvilas M., Raginis V., Orlova K., Katauskas M. Grunto, veikiamo periodinemis apkrovomis, elgsenos tyrimai. Geologija. Geografija. 2018. T. 4(4). ISSN 2351-7549.

Straipsnyje yra apžvelgtos grunto liekamosios deformacijos ir įvertintas liekamasis grunto deformacijų modulis esant skirtingam grunto apkrovimų ciklų kiekiui. Šie tyrimai leidžia prognozuoti inžinerinio geologinio pagrindo, kuris perima apkrovas, elgseną esant skirtingam apkrovimo ciklų kiekiui (intensyvumui). Bandymai atlikti su triašio slegio aparatu, imituojant automobilių kelių sukeliamas ir perduodamas apkrovas pagrindams. Gruntas ištirtas esant skirtingiems apkrovų intensyvumams ir grunto gyliams. Gauti rezultatai parodè, kad liekamasis grunto deformaciju modulis labai priklauso nuo grunto bandinio apkrovimo ciklų kiekio ir apkrovų intensyvumo. Nustatyta, kad bendrosios tirto grunto deformacijos nebuvo didesnés nei 2,0 \%. Matuojant bandinio vertikalias deformacijas ties bandinio viduriu, liekamosios deformacijos nebuvo didesnès nei $0,5 \%$. Gauti rezultatai yra labai vertingi prognozuojant / modeliuojant inžinerinio geologinio pagrindo elgseną esant skirtingam apkrovų ciklų kiekiui ir intensyvumui. Rezultatus galima lengvai pritaikyti tokio paties grunto sluoksnio skirtingiems gyliams (įvertinti liekamąji grunto sustiprèjimą).

Raktažodžiai: deformacijų modulis, liekamasis deformacijų modulis, liekamosios deformacijos, ciklinès apkrovos, triašio slègio bandymas

\section{IVADAS}

Dažniausiai gruntai ir jų inžinerinès geologinès sąlygos (Dundulis ir kt., 2008) yra tiriamos statinemis apkrovomis. Atliekant inžinerinius geologinius tyrimus plačiai naudojami statiniai kūginès penetracijos bandymai (Žaržojus, Dundulis, 2010). Kartais, jei yra neįmanoma ištirti grunto kūginès penetracijos, taikomas dinaminis zondavimas (Žaržojus ir kt., 2013; Žaržojus, Kelevišius, 2016). Greta tyrimų vietos yra tiriamas gruntas ji išgręžiant ir paimant nesuardytos struktūros grunto bandinius, kurie vèliau bandomi laboratorinemis sąlygomis. Laboratorijoje nustatomos fizinès ir mechaninès savybès. Mechaninès savybės dažniausiai yra tiriamos su kompresiniu (odometriniu) aparatu (Amšiejus ir kt., 2010; Skuodis ir kt., 2014; Skuodis ir kt., 2017), tiesioginio kirpimo (Medzvieckas ir kt., 2017; Dirgèlienè ir kt., 2017) arba triašio slègio prietaisais (Dirgèlienè, 2013; Lekstutytė ir kt., 2018). 
Tiriant gruntą su triašio slégio aparatu galima nustatyti daug grunto mechaninių savybių. Taip pat gruntas gali būti tiriamas imituojant drenuojančias / nedrenuojančias ir / arba konsoliduotas / nekonsoliduotas sąlygas (Muraro ir kt. 2018; Giger ir kt., 2018). Triašio slègio aparatu yra įmanoma imituoti ciklines, dinamines, periodines arba kartotinai kintamas apkrovas (Chen ir kt., 2018; Jamali ir kt., 2018; Polito, Moldenhauer, 2018). Bandant grunto bandinius ne statinemis apkrovų sąlygomis galima nustatyti liekamąsias grunto deformacines savybes (Arshad ir kt., 2018; George ir kt., 2018). Taigi, žinant geotechninès konstrukcijos eksploatacijos elgseną, galima parinkti tinkamą metodą grunto deformacinių savybių tyrimams (1 pav.), nes deformacinių savybių rodikliai skirtingose deformacijų zonose yra nevienodi.

Šio straipsnio tikslas - nustatyti grunto veikiamo periodinèmis apkrovomis elgseną su triašio slègio aparatu. Šie tyrimai leidžia nustatyti grunto liekamąji deformacijų modulị ir jo priklausomybę nuo apkrovų ciklų.

\section{EKSPERIMENTINIO BANDYMO APRAŠYMAS}

Tyrimuose naudotas gruntas - žvyringas smèlis (grSa). Šio grunto granuliometrinè kreivè pateikta 2 pav. Nustatytas vienodumo koeficientas $C_{U}=8,35$ ir sanklodos rodiklis $C_{C}=0,77$. Šio grunto kietųjų dalelių tankis $\rho_{s}=2,7219 \mathrm{~g} / \mathrm{cm}^{3}$. Prieš plaunant grunto bandini, bendra tiriamo grunto masė buvo 218,87 g. Po plovimo grunto bandinio mase $-201,72$ g. Nustatyta, kad šio grunto sudétyje yra dulkio ir molio, kurio mase $-18,23 \mathrm{~g}$, t. y. $8,33 \%$.

$\mathrm{Su}$ šiuo gruntu atlikti triašio slègio bandymai taikant periodines apkrovas. Tirtas $100 \mathrm{~mm}$ skersmens ir $200 \mathrm{~mm}$ aukščio grunto bandinys. Pasirinktos bandymų sąlygos - izotropiniai neprisotinti, nekonsoliduoti ir drenuoti bandymai (LST EN 13286-7:2004). Šios bandymų sąlygos imituoja automobilių kelių apkrovas su pasirinktu $1 \mathrm{~Hz}$ dažniu (pravažiuojanti pirma ir antra automobilio ašis). Kad būtų ịmanoma tiksliai išmatuoti kiekvieno ciklo amplitudžių didžiausias

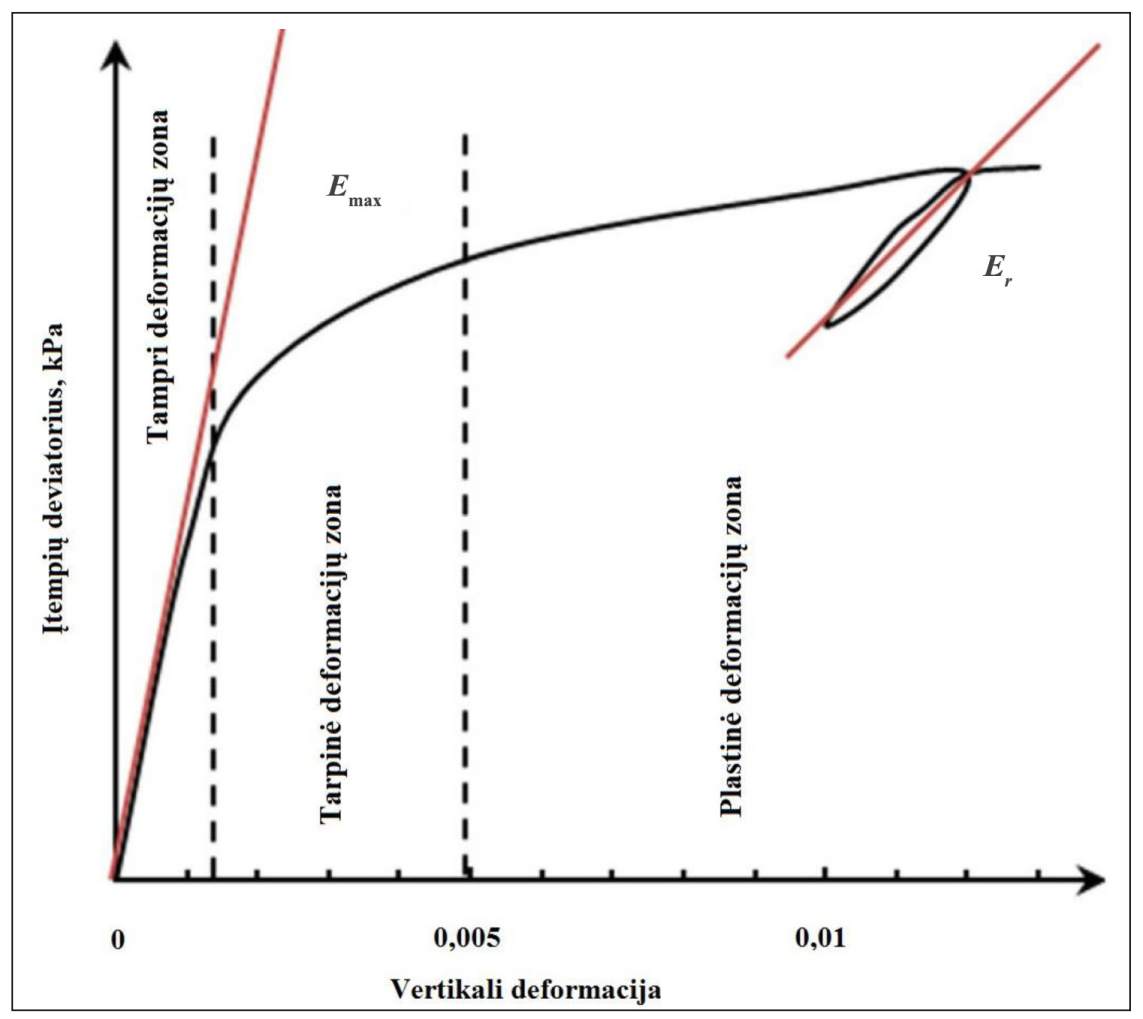

1 pav. Skirtumai tarp grunto deformacijų zonų ir deformacijų modulių (Sas ir kt., 2016)

Fig. 1. Differences between soil deformation zones and Young's modulus (Sas et al., 2016) 


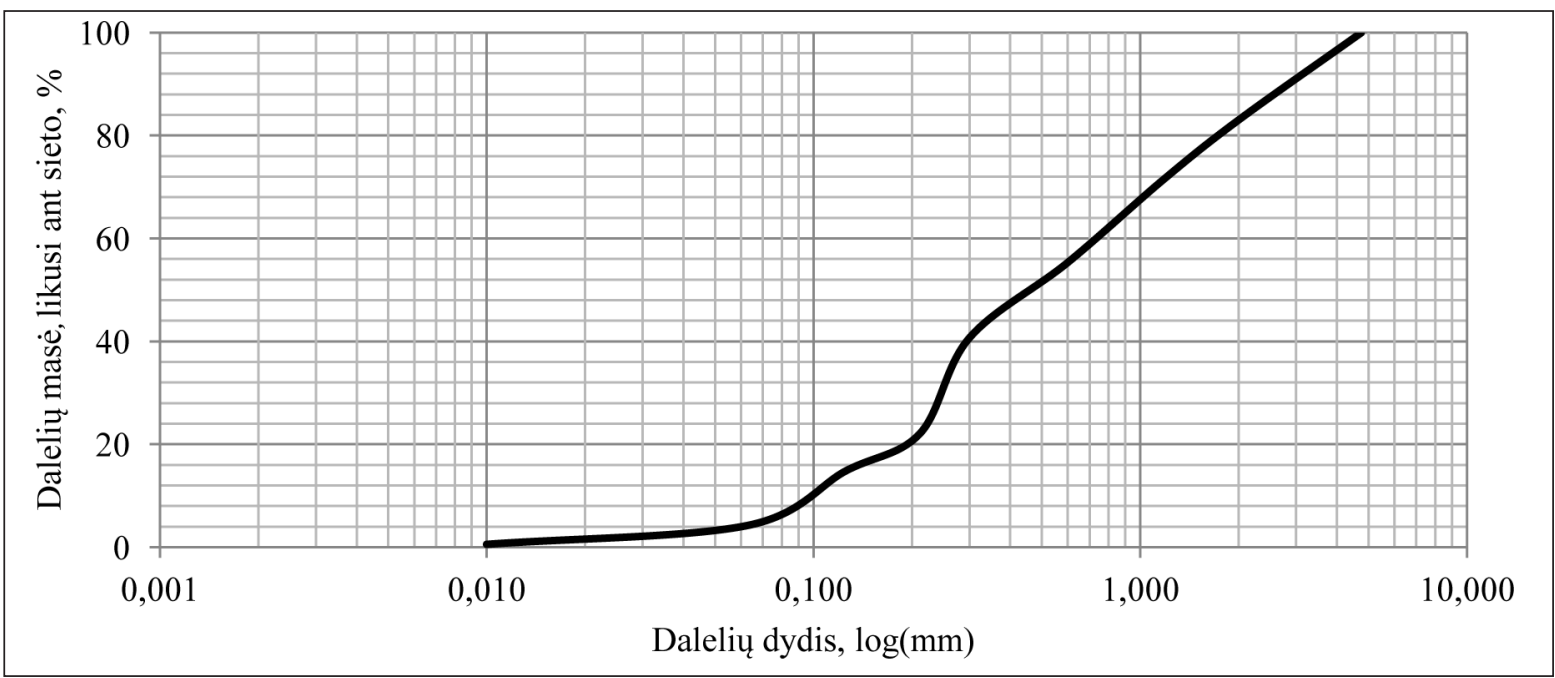

2 pav. Tirto grunto granuliometrinè sudetis

Fig. 2. Granulometric curve of investigated soil

ir mažiausias vertes, bandymui buvo naudojamas duomenų įrašymo intervalas - 50 duomenų per vieną sekundę. Bandymų metu atkurtas grunto drègnis $w=8,00 \%$. Bandiniai paruošti su pradiniu grunto tankiu $\rho=2,32 \mathrm{~g} / \mathrm{cm}^{3}$. Ant paruošto bandinio papildomai sumontuotas radialinis poslinkių indikatorius, matuojantis bandinio pletimąsi arba traukimąsi, bei du papildomi vertikaliu deformacijų indikatoriai, matuojantys bandinio vidurio suspaudimą (3 pav.). Papildomų indikatorių
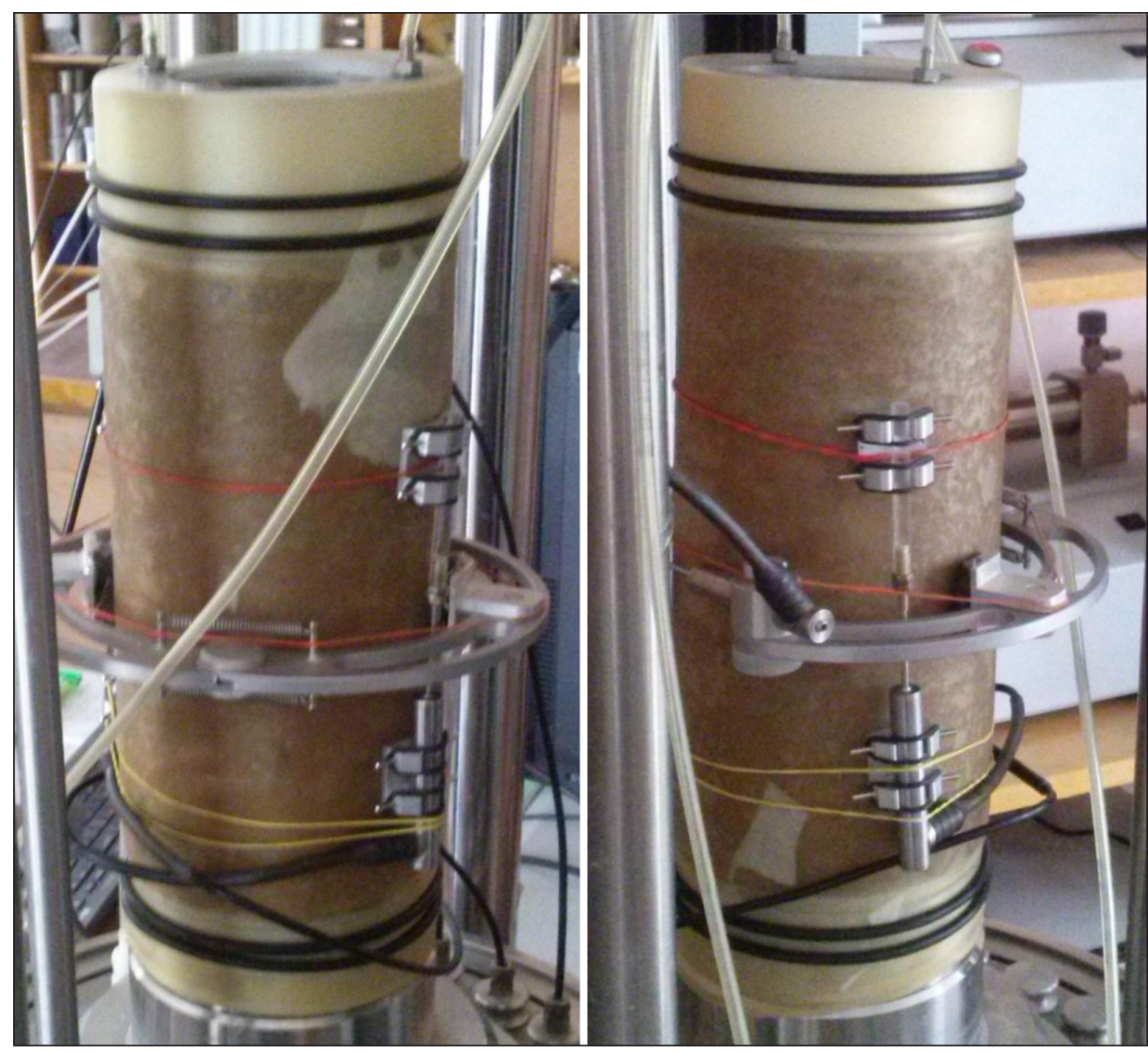

3 pav. Papildomų indikatorių montavimas prieš bandymą Fig. 3. Mounting additional indicators before test 
pozicijos atitinka reikalavimus, pateiktus LST EN 13286-7:2004.

Bandyme taikytas celès slègis $\sigma_{3}=70 \mathrm{kPa}, \mathrm{o}$ deviatorinis ittempių pokytis $\sigma_{d}=10-200 \mathrm{kPa}$. Bandymų pradžioje atlikta 20000 periodinių ciklinių apkrovimų ir ištirta grunto elgsena veikiant gruntą $1 \mathrm{~Hz}$ dažniu su kintamu įtempiu deviatoriumi $\sigma_{d}=10-200 \mathrm{kPa}$. Esant skirtingam ciklų kiekiui, pagal LST EN 13286-7:2004, nustatytas liekamasis deformacijų modulis: $E_{r}=\left(\sigma_{1}^{r^{2}}+\right.$ $\left.\sigma_{1}^{r} \sigma_{3}^{r}-2 \sigma_{3}^{r^{2}}\right) /\left(\sigma_{1}^{r} \varepsilon_{1}^{r}+\sigma_{3}^{r} \varepsilon_{1}^{r}-2 \sigma_{3}^{r} \varepsilon_{3}^{r}\right)$. Po 20000 cikluc gruntas tirtas atskirai po 100 ciklų, keičiant celès slègi ir ịtempių deviatorių (1 lentelè).

Atlikus bandymus pagal 1 lenteleje nurodytas sąlygas, apskaičiuotas liekamasis deformacijų modulis $E_{r}$ ir liekamosios vertikalios $\varepsilon_{1}^{r}$ ir radialinès $\varepsilon_{3}^{r}$ deformacijos (pagal LST EN 132867:2004). Atliekant skaičiavimus vertinti paskutiniai 10 ciklų rezultatai.

\section{REZULTATŲ ANALIZE்}

Atlikus visus numatytus bandymų etapus, grunto bandinys nesuiro (4 pav.). Vertinant grunto bandinio formos pokyčius po bandymo, galima konstatuoti, kad bandinys per visą bandinio aukštị susispaudè mažiau nei 2,0 \%. Vertikalios deformacijos ties bandinio viduriu nebuvo didesnès nei $0,5 \%$. Taip pat bandinys šiek tiek išsiplètè ties bandinio viduriu (pradèjo formuotis statinès forma).

Vertikalios deformacijos, kurios buvo tiriamos per visą bandinio aukští, pradejjo stabilizuotis esant 5000 apkrovimo ciklų ir praktiškai nepakito iki 20000 apkrovimo ciklų (5 pav.). Didžiausios deformacijos aptiktos tiriant gruntą nuo 1 iki 10 apkrovimo ciklo. Per visą apkrovimo ciklą buvo sukuriamas deviatorinis itempiu pokytis $\sigma_{d}=10$ $200 \mathrm{kPa}$. Norint išsamiau įvertinti grunto elgseną, reikia atsižvelgti i rezultatus, pateiktus 2 lentelèje.

1 lentelè. Bandymų metodika esant ciklų skaičiui 20 001-21900

Table 1. Testing methodology for cycles 20 001-21900

\begin{tabular}{|c|c|c|c|}
\hline $\begin{array}{c}\text { Ciklai } \\
\text { Cycles, N (-) }\end{array}$ & $\begin{array}{l}\text { Celès slègis } \\
\text { Cell pressure } \sigma_{3} \text {, } \\
\text { kPa }\end{array}$ & $\begin{array}{c}\text { Mažiausias įtempių deviatorius } \\
\text { Stress deviator (minimum) } \sigma_{d \text {, min' }} \\
\text { kPa }\end{array}$ & $\begin{array}{c}\text { Didžiausias įtempių deviatorius } \\
\text { Stress deviator (maximum) } \sigma_{d \text {, max' }} \\
\text { kPa }\end{array}$ \\
\hline 20100 & 20 & 10 & 20 \\
\hline 20200 & 20 & 10 & 35 \\
\hline 20300 & 20 & 10 & 50 \\
\hline 20400 & 20 & 10 & 70 \\
\hline 20500 & 35 & 10 & 35 \\
\hline 20600 & 35 & 10 & 50 \\
\hline 20700 & 35 & 10 & 70 \\
\hline 20800 & 35 & 10 & 90 \\
\hline 20900 & 35 & 10 & 120 \\
\hline 21000 & 50 & 10 & 50 \\
\hline 21100 & 50 & 10 & 70 \\
\hline 21200 & 50 & 10 & 90 \\
\hline 21300 & 50 & 10 & 120 \\
\hline 21400 & 50 & 10 & 160 \\
\hline 21500 & 70 & 10 & 70 \\
\hline 21600 & 70 & 10 & 90 \\
\hline 21700 & 70 & 10 & 120 \\
\hline 21800 & 70 & 10 & 160 \\
\hline 21900 & 70 & 10 & 200 \\
\hline
\end{tabular}




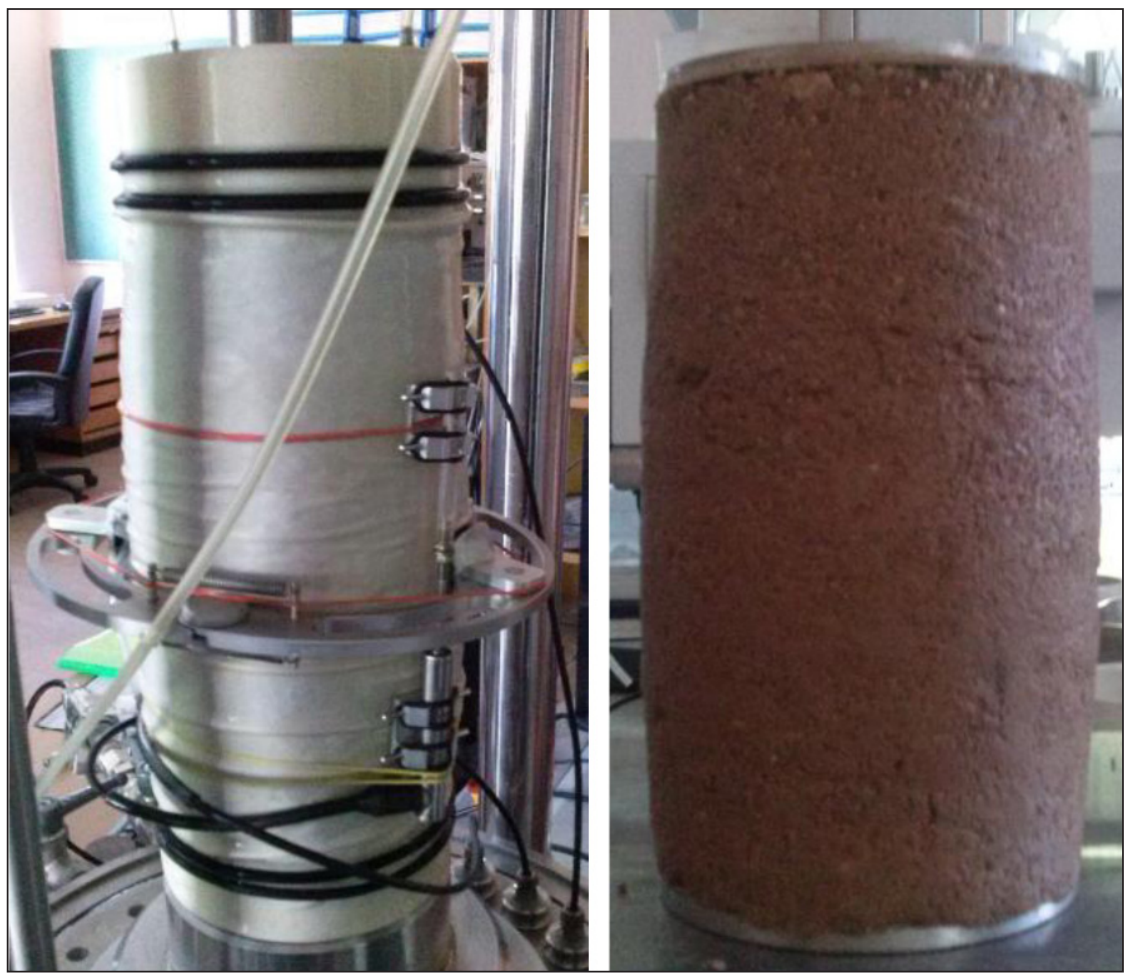

4 pav. Grunto bandinio forma po bandymų

Fig. 4. Shape of soil sample after tests

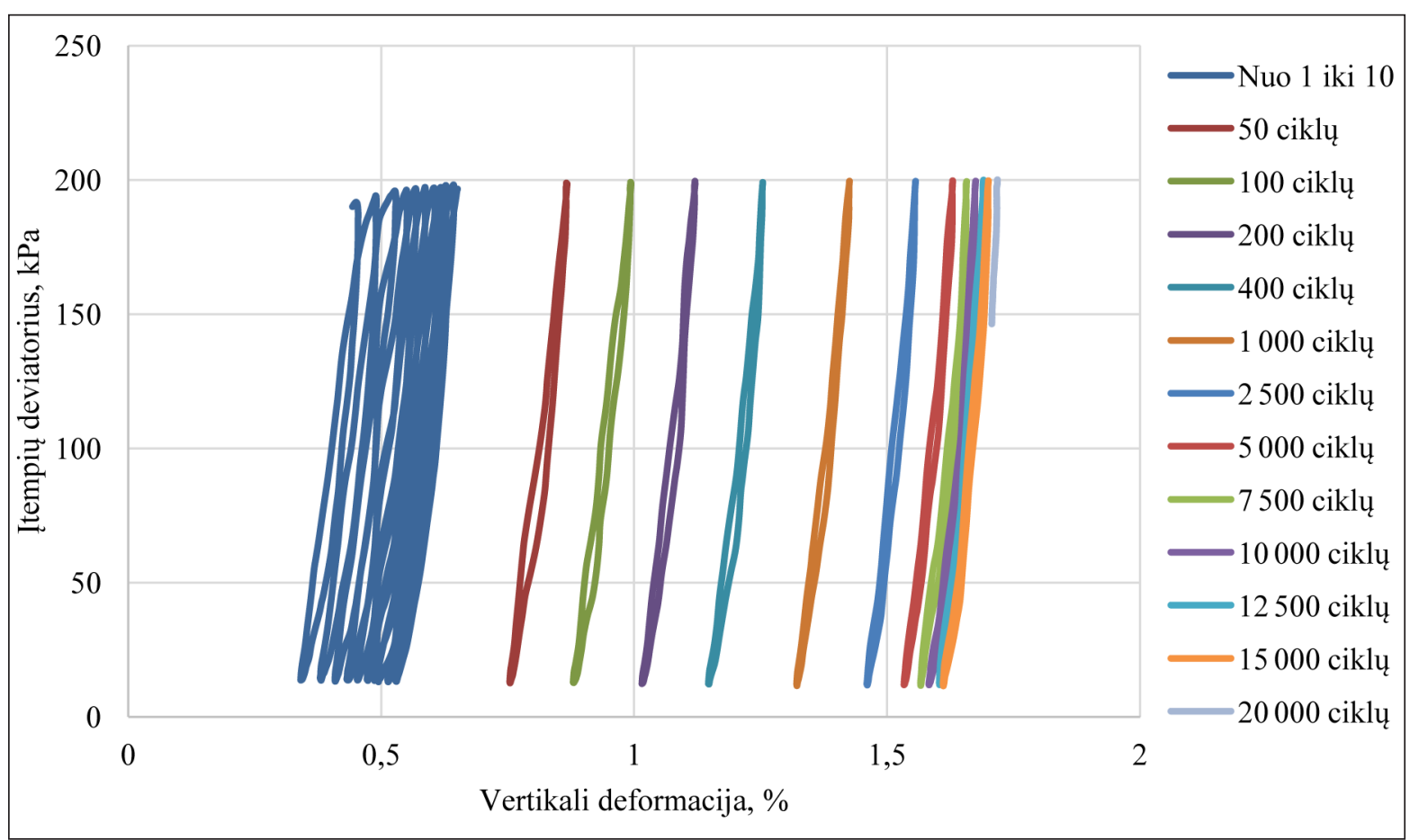

5 pav. Vertikalių deformacijų pokytis, priklausomai nuo apkrovimo ciklų

Fig. 5. Vertical strain progress according to loading cycles

Analizuojant rezultatus, pateiktus 2 lentelëje, dančių deformacijų veikiant kintamam ịtempių pastebima, kad liekamasis tamprumo modulis $E_{r}$ deviatoriui. Liekamosios deformacijos, kurios labai priklauso nuo ciklų skaičiaus $N$ ir atsiran- matuotos ties bandinio viduriu, neviršijo 0,5\% 
2 lentelè. Grunto, apkrauto 20000 ciklų apkrova elgsenos rezultatai

Table 2. Results of soil behaviour loaded with 20000 cycles

\begin{tabular}{|c|c|c|c|c|c|c|c|c|c|}
\hline \multirow[t]{2}{*}{$\begin{array}{l}\text { Ciklai } \\
\text { Cycles, } \\
N(-)\end{array}$} & \multicolumn{2}{|c|}{$\begin{array}{l}\text { Celès slègis } \\
\text { Cell pressure, } \\
\sigma_{3}(\mathrm{kPa})\end{array}$} & \multicolumn{2}{|c|}{$\begin{array}{c}\text { Itempių } \\
\text { deviatorius } \\
\text { Stress deviator, } \\
\sigma_{d}(\mathrm{kPa})\end{array}$} & \multicolumn{2}{|c|}{$\begin{array}{c}\text { Liekamosios } \\
\text { deformacijos } \\
\text { Residual strains, \% }\end{array}$} & \multicolumn{2}{|c|}{$\begin{array}{c}\text { Liekamosios ciklo } \\
\text { deformacijos } \\
\text { Residual cycle strains, } \\
\%\end{array}$} & \multirow{2}{*}{$\begin{array}{c}\text { Liekamasis tam- } \\
\text { prumo modulis } \\
\text { Residual Young's } \\
\text { modulus, Mpa }\end{array}$} \\
\hline & $\min$ & $\max$ & $\min$ & $\max$ & $\varepsilon_{1}^{r}$ & $\varepsilon_{3}^{r}$ & $\varepsilon_{1}^{p}$ & $\varepsilon_{3}^{p}$ & \\
\hline 1 & 62,45 & 65,12 & 13,68 & 190,01 & 0,000690 & 0,000190 & 0,002687 & 0,000059 & 259,47 \\
\hline 10 & 63,34 & 65,80 & 13,42 & 195,48 & 0,000489 & 0,000186 & 0,007833 & 0,000165 & 565,33 \\
\hline 20 & 64,60 & 69,58 & 12,80 & 199,59 & 0,000349 & 0,000189 & 0,026478 & 0,000458 & 406,59 \\
\hline 50 & 66,65 & 69,28 & 12,85 & 198,74 & 0,000378 & 0,000129 & 0,021198 & 0,000478 & 988,14 \\
\hline 100 & 67,80 & 69,48 & 12,58 & 199,08 & 0,000838 & 0,000198 & 0,028314 & 0,000691 & 383,49 \\
\hline 200 & 68,06 & 70,37 & 12,50 & 199,14 & 0,000578 & 0,000164 & 0,030661 & 0,001298 & 602,00 \\
\hline 400 & 68,94 & 70,58 & 12,29 & 198,94 & 0,000475 & 0,000203 & 0,033561 & 0,001510 & 595,02 \\
\hline 1000 & 69,72 & 70,81 & 11,89 & 199,15 & 0,000332 & 0,000076 & 0,033480 & 0,001898 & 847,34 \\
\hline 2500 & 69,72 & 71,04 & 12,05 & 199,54 & 0,000855 & 0,000443 & 0,035945 & 0,001708 & 268,23 \\
\hline 5000 & 69,73 & 70,86 & 11,75 & 199,71 & 0,000998 & 0,000169 & 0,035260 & 0,002043 & 492,38 \\
\hline 7500 & 69,72 & 70,99 & 11,63 & 199,25 & 0,001018 & 0,000224 & 0,034355 & 0,002176 & 210,96 \\
\hline 10000 & 69,73 & 71,13 & 11,94 & 199,65 & 0,000686 & 0,000209 & 0,034290 & 0,002266 & 697,27 \\
\hline 12500 & 69,73 & 71,04 & 11,72 & 199,59 & 0,000625 & 0,000150 & 0,035616 & 0,002297 & 372,21 \\
\hline 15000 & 69,73 & 71,05 & 11,57 & 199,63 & 0,000390 & 0,000094 & 0,035880 & 0,002145 & 739,19 \\
\hline 20000 & 69,72 & 70,80 & 24,55 & 199,40 & 0,000574 & 0,000111 & 0,036302 & 0,002566 & 1103,91 \\
\hline
\end{tabular}

(6 pav.). Ši tendencija aptikta ir analizuojant atskirų ciklų liekamąsias deformacijas. Tiriamo grunto bandinio pletimosi liekamosios deformacijos taip pat nebuvo žymios. Vertinant atskirų ciklų liekamąsias plètimosi deformacijas ties bandinio viduriu, pastebima, kad nuo 5000 iki 20000

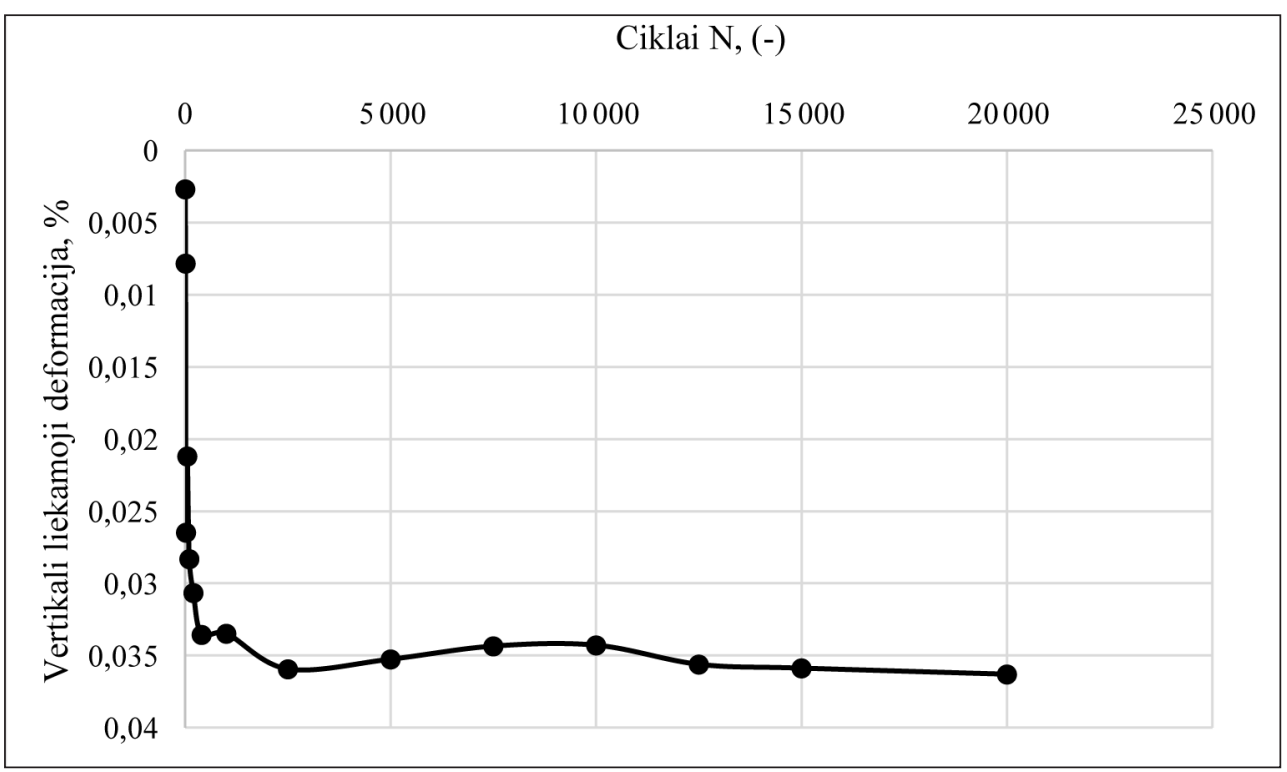

6 pav. Vertikalių liekamųjų deformacijų (ties bandinio viduriu) pokytis, priklausomai nuo apkrovimo ciklų

Fig. 6. Residual vertical strain (in the middle of the sample) progress according to loading cycles 
ciklų šios deformacijos nusistovejjo ir praktiškai nekito.

Pagal gautą rezultatų kreivès pobūdị (6 pav.), tirtas gruntas priskiriamas C3 klasei (vadovaujantis LST EN 13286-7:2004), t. y. stabili deformacinè kreivè. Priskyrimas C3 klasei atliekamas pagal charakteristinès liekamosios ašinès deformacijos vertinimą prie 100 ir 20000 apkrovimo ciklų $\left(\varepsilon_{1}^{c}=\varepsilon_{1}^{p}(20000)-\varepsilon_{1}^{p}(100)\right)$. Nagrinejjamu atveju, $\varepsilon_{1}^{c}=0,007988$, tai yra daugiau nei 0,006 .

Kadangi bendroji tirto žvyringo smèlio (grSa) bandinio aukščio vertikali deformacija buvo mažesnè nei 2,0 \% (5 pav.), grunto bandinys papildomai ištirtas pagal bandymų metodiką, nurodytą 1 lentelèje. Nustatytas tiriamo grunto liekamasis deformacijų modulis (3 lentelè), esant skirtingiems imituojamų apkrovų intensyvumams ir grunto gyliams.

Nustatytas grunto liekamasis deformacijų modulis kinta, nes su celès slègiu yra imituojamas skir- tingas tiriamo grunto gylis $\left(\sigma_{3}=20-70 \mathrm{kPa}\right)$. Bandyme imituojant skirtingą gyli, gruntas ištirtas ir su skirtingais apkrovų intervalais $\left(\sigma_{d}=10-200 \mathrm{kPa}\right)$. Analizuojant liekamojo deformacijų modulio vertes pastebèta, kad mažiausios reikšmès gaunamos, kai bandinys yra veikiamas įtempių deviatoriumi, kuris yra praktiškai tokio pačio dydžio kaip celès slègis. Nustatytos didžiausios liekamojo deformacijų modulio vertès, kai įtempių deviatorius bandymų metu yra nuo 1,4 iki 2,5 kartų didesnis nei celès slègis.

\section{IŠVADOS}

Apibendrinant gautus rezultatus galima teigti:

1. Liekamasis deformacijų modulis labai priklauso nuo deformacijų dydžio esant skirtingiems apkrovimo ciklams.

2. Tiriamo grunto atveju, grunto deformacijų elgsena priskiriama stabilioms deformacijoms,

3 lentelè. Grunto liekamojo deformacijų modulio nustatymas

Table 3. Soil residual Young's modulus determination

\begin{tabular}{|c|c|c|c|c|c|c|c|}
\hline \multirow{2}{*}{$\begin{array}{l}\text { Ciklai } \\
\text { Cycles, } \\
\mathrm{N}(-)\end{array}$} & \multicolumn{2}{|c|}{$\begin{array}{c}\text { Celès slègis } \\
\text { Cell pressure, } \\
\sigma_{3}(\mathrm{kPa})\end{array}$} & \multicolumn{2}{|c|}{$\begin{array}{c}\text { Ittempių deviatorius } \\
\text { Stress deviator, } \\
\sigma_{d}(\mathrm{kPa})\end{array}$} & \multicolumn{2}{|c|}{$\begin{array}{c}\text { Liekamosios } \\
\text { deformacijos } \\
\text { Residual strains, \% }\end{array}$} & \multirow{2}{*}{$\begin{array}{c}\text { Liekamasis } \\
\text { tamprumo modulis } \\
\text { Residual Young's modulus, MPa }\end{array}$} \\
\hline & $\min$ & $\max$ & $\min$ & $\max$ & $\varepsilon_{1}^{r}$ & $\boldsymbol{\varepsilon}_{3}^{r}$ & \\
\hline 20100 & 20,04 & 20,28 & 9,82 & 19,29 & 0,000889 & 0,000277 & 22,25 \\
\hline 20200 & 19,94 & 19,94 & 10,54 & 34,13 & 0,001689 & 0,000277 & 16,78 \\
\hline 20300 & 19,95 & 20,03 & 10,78 & 48,84 & 0,001010 & 0,000272 & 90,68 \\
\hline 20400 & 19,95 & 20,00 & 11,42 & 69,22 & 0,001338 & 0,000212 & 55,29 \\
\hline 20500 & 34,81 & 35,79 & 10,30 & 34,36 & 0,001534 & 0,000395 & 18,57 \\
\hline 20600 & 34,69 & 35,37 & 10,62 & 49,03 & 0,000549 & 0,000268 & 149,56 \\
\hline 20700 & 34,17 & 35,68 & 11,20 & 69,14 & 0,000863 & 0,000166 & 85,34 \\
\hline 20800 & 34,12 & 35,72 & 11,67 & 88,92 & 0,001391 & 0,000225 & 65,39 \\
\hline 20900 & 34,00 & 35,73 & 12,34 & 119,24 & 0,000631 & 0,000113 & 188,62 \\
\hline 21000 & 49,82 & 51,02 & 10,59 & 49,29 & 0,000994 & 0,000147 & 83,34 \\
\hline 21100 & 49,82 & 50,85 & 11,05 & 69,27 & 0,000883 & 0,000138 & 112,60 \\
\hline 21200 & 49,83 & 50,05 & 11,19 & 89,00 & 0,001411 & 0,000178 & 74,51 \\
\hline 21300 & 49,82 & 50,64 & 11,67 & 119,06 & 0,000446 & 0,000080 & 691,89 \\
\hline 21400 & 49,82 & 50,68 & 12,08 & 159,25 & 0,000643 & 0,000209 & 239,81 \\
\hline 21500 & 69,73 & 71,19 & 10,48 & 69,44 & 0,000695 & 0,000156 & 186,30 \\
\hline 21600 & 69,73 & 71,10 & 10,90 & 89,34 & 0,000986 & 0,000138 & 372,14 \\
\hline 21700 & 69,83 & 70,79 & 11,39 & 119,23 & 0,000588 & 0,000087 & 1714,93 \\
\hline 21800 & 69,73 & 70,68 & 11,97 & 159,13 & 0,000624 & 0,000111 & 329,35 \\
\hline 21900 & 69,72 & 70,72 & 12,25 & 199,43 & 0,000633 & 0,000212 & 500,28 \\
\hline
\end{tabular}


pagal vertikalios liekamosios deformacijos ties bandinio viduriu ir apkrovu ciklų skaičių.

3. Pagal charakteristinès liekamosios ašinès deformacijos vertinimą, tiriamas gruntas priskiriamas C3 klasei.

4. Atliekant inžinerinius geologinius ir geotechninius tyrinejimus tose vietose, kur vèliau grunto sluoksniai bus apkraunami ciklinemis arba kartotinai kintamomis apkrovomis yra racionalu ištirti liekamąji grunto deformacijų modulį.

5. Liekamasis deformacijų modulis taip pat labai priklauso nuo tiriamo grunto gylio apkrovų.

6. Siūloma atsakingas automobilių kelių ir geležinkelių atkarpas ištirti šiame straipsnyje pristatytu metodu, nes Lietuvoje tokie tyrimai dar tik pradedami. Gauti rezultatai yra labai vertingi prognozuojant inžinerinio geologinio pagrindo elgseną esant skirtingam apkrovų ciklų kiekiui ir intensyvumui.

\section{PADE்KA}

Tyrimų autoriai dèkingi Vilniaus Gedimino technikos universiteto Civilinès inžinerijos mokslo centrui už suteiktą tyrimų bazę ir bandymuose naudotas medžiagas.

Gauta 20190107

Priimta 20190206

\section{LITERATŪRA}

1. Amšiejus J., Kačianauskas R., Norkus A., Tumonis L. 2010. Investigation of the sand porosity via oedometer testing. The Baltic Journal of Road and Bridge Engineering. 5(3): 139-147.

2. Arshad A. K., Shaffie E., Ismail F., Hashim W., Rahman Z. A. 2018. Resilient modulus of crushed granite aggregate base for use in mechanistic pavement design. International Journal of Civil Engineering and Technology. 9(9): 1151-1160.

3. Chen R., Yao W., Lu F., Xia K. 2018. Evaluation of the stress equilibrium condition in axially constrained triaxial SHPB tests. Experimental Mechanics. 58(2018): 527-531.

4. Dirgèlienè N. 2013. Grunto tyrimas triašio slègio aparatu. Vilnius: Technika. 43 p.

5. Dirgèlienè N., Skuodis Š., Grigusevičius A. 2017. Experimental and numerical analysis of direct shear test. Procedia Engineering, Modern Building Materials, Structures and Techniques, MBMST 2016. Amsterdam: Elsevier Ltd. 172(2017): 218-225.
6. Dundulis K., Kacynski R. R., Krauzlis K. S., Žaržojus G. 2008. Engineering geological properties of Vilnius and Warsaw region tills as building subsoils. Geologija. 50: S11-S15.

7. George V., Kumar A. 2016. Studies on modulus of resilience using cyclic tri-axial test and correlations to PFWD, DCP, and CBR. International Journal of Pavement Engineering. 19(11): 976-985.

8. Giger S. B., Ewy R. T., Favero V., Stankovic R., Keller L. M. 2018. Consolidated-undrained triaxial testing of Opalinus Clay: Results and method validation. Geomechanics for Energy and the Environment. 14(2018): 16-28.

9. Jamali H., Tolooiyan A., Dehghani M., Asakereh A., Kalantari B. 2018. Long-term dynamic behaviour of Coode Island Silt (CIS) containing different sand content. Applied Ocean Research. 73(2018): 59-69.

10. Lekstutytè I., Gadeikis S., Žaržojus G., Skuodis Š. 2018. Medininkų ledynmečio periodo moreninių gruntų mechaninès savybès. Geologija. Geografija. 4(2): 69-78.

11. LST EN 13286-7:2004. Birieji ir hidrauliniais rišikliais sujungti mišiniai. 7 dalis. Biriuju mišiniu periodinés apkrovos triašis bandymas.

12. Medzvieckas J., Dirgèlienè N., Skuodis Š. 2017. Stress-strain states differences in specimens during triaxial compression and direct shear tests. Procedia Engineering, Modern Building Materials, Structures and Techniques, MBMST 2016. Amsterdam: Elsevier Ltd. 172(2017): 739-745.

13. Muraro S., Mašin D., Jommi C. 2018. Applicability of hypoplasticity to reconstituted peat fromdrained triaxial tests. Numerical and Analytical Methods in Geomechanics. 42(2018): 2049-2064.

14. Polito C., Moldenhauer H. 2018. Energy dissipation and pore pressure generation in stress- and straincontrolled cyclic triaxial tests. Geotechnical Testing Journal (in press).

15. Sas W., Gluchowski A., Gabrys K., Sobol E., Szymanski A. 2016. Studies on cyclic and dynamic loading on cohesive soil in road engineering. Proceedings of 13th Baltic Sea Geotechnical Conference "Historical Experience and Challenges of Geotechnical Problems in Baltic Sea Region". Lithuanian Geotechnical Society. Lithuania, 22-24 September. p. 85-92.

16. Skuodis Š., Markauskas D., Norkus A., Žaržojus G., Dirgèlienè N. 2014. Testing and numerical simulation of Holocene marine sand uniaxial compression at Lithuanian coast. Baltica. 27(1): 33-44.

17. Skuodis Š., Karaman A. H., Dirgèlienè N. 2017. Comparison of one-step and step-wise compression tests. Geologija, Geografija. 3(1): 1-10.

18. Žaržojus G., Dundulis K. 2010. Problems of correlation between dynamic probing test (DPSH) and cone penetration test (CPT) for cohesive soils of Lithuania. The Baltic Journal of Road and Bridge Engineering. 5(2): 69-75. 
19. Žaržojus G., Kelevišius K. 2016. Smèlio tyrimai patobulintu dinaminiu penetrometru. Geologija. Geografija. 2(2): 84-91.

20. Žaržojus G., Kelevišius K., Amšiejus A. 2013. Energy transfer measuring in dynamic probing test in layered geological strata. Procedia Engineering, Modern Building Materials, Structures and Techniques, MBMST 2016. Amsterdam: Elsevier Ltd. 57(2013): 1302-1308.

\section{Šarūnas Skuodis, Rokas Karpis, Mindaugas Zakarka, Modestas Gedvilas, Vytautas Raginis, Kornelija Orlova, Mantas Katauskas}

\section{INVESTIGATION OF SOIL BEHAVIOUR AFFECTED WITH CYCLIC LOADS}

\section{Summary}

This paper presents the results of a cyclic triaxial test on soil, namely gravely sand. These tests are very important for the evaluation of engineering geological and geotechnical conditions when the strata is loaded with cyclic loads. The provided research work shows the resilient Young's modulus change according to cycles quantity, stress deviator change and applied cell pressure. During the investigations, the constant cycles frequency $(1 \mathrm{~Hz})$ was applied. This frequency imitates moving road loads (moving car's first and second axis load on road construction). Cycles quantity could be used for ranking materials on the basis of their plastic deformability. During this research it was obtained that investigated soil behaviour acts as stable deformation behaviour (plastic shakedown). The conditioning phase was realised using stress deviator values from 10 to $200 \mathrm{kPa}$ with total cycles quantity 20000 . Analysing soil behaviour at the conditioning phase it was obtained that total sample deformation is less than $2.0 \%$ and resilient strain in the middle of the sample is less than $0.5 \%$. According to characteristic permanent axial strain, investigated soil is classified as C3 class. The repeated loading phase was realised using stress deviators from 10 to $200 \mathrm{kPa}$ with cell pressure from 20 to $70 \mathrm{kPa}$. Repeated loading for resilient testing showed that the resilient Young's modulus depends on applied cell pressure and stress deviator minimum and maximum values. The investigated soil sample shape after tests was almost the same as before the tests. Obtained results are very valuable when it is necessary to evaluate soil behaviour under different cyclic loading and load stresses. Also, when repeated loading tests are provided with different cell pressures it is possible to imitate soil layer behaviour in different depths.

Keywords: Young's modulus, resilient Young's modulus, resilient strains, cyclic load, triaxial test 